\title{
Feasibility and Safety of CT-guided Intrathoracic and Bone Re-biopsy for Non-small Cell Lung Cancer
}

\author{
TOMOHIRO MATSUMOTO ${ }^{1 *}$, TERUMITSU HASEBE $^{1^{*}}$, YASUTAKA BABA $^{2^{*}}$, \\ KEIGO CHOSA ${ }^{2}$, SHOTA KONDO ${ }^{2}$, SHUNSUKE YAMADA ${ }^{3}$, RIKA YOSHIMATSU ${ }^{4}$, \\ TETSUYA KUBOTA ${ }^{5}$, KAZUNORI FUJITAKA ${ }^{6}$, KAZUO AWAI ${ }^{2}$ and TAKUJI YAMAGAMI ${ }^{1,4^{*}}$ \\ ${ }^{1}$ Department of Radiology, and ${ }^{3}$ Department of General Thoracic Surgery, \\ Tokai University Hachioji Hospital, Tokai University School of Medicine, Tokyo, Japan; \\ ${ }^{2}$ Diagnostic Radiology, and ${ }^{6}$ Department of Respiratory Medicine, \\ Graduate School of Biomedical and Health Sciences, Hiroshima University, Hiroshima, Japan; \\ Departments of ${ }^{4}$ Radiology, and ${ }^{5}$ Hematology and Respiratory Medicine, \\ Kochi University, Kochi Medical School, Kochi, Japan
}

\begin{abstract}
Aim: This study aimed to retrospectively determine the feasibility and safety of computed tomography $(C T)$-guided intrathoracic and bone re-biopsy for patients with non-small cell lung cancer (NSCLC). Materials and Methods: Seventeen patients underwent CT-guided intrathoracic or bone re-biopsy for the determination of epidermal growth factor receptor (EGFR) T790M mutation and/or programmed cell deathligand 1 (PD-L1) expression. The characteristics of each lesion, success rate of analyses, and complications were investigated. Results: Specimens from 16 out of the 17 patients were adequate for evaluation of EGFR T790M mutation and/or PD-L1 expression. The mean diameter of the lesions was $40 \mathrm{~mm}$, the mean procedural time was 24 minutes, and the median number of punctures was 2. There were no significant differences in lesion characteristics and success rates between CT-guided intrathoracic and bone re-biopsies. No serious complications occurred. Conclusion: Both CTguided intrathoracic and bone re-biopsies for patients with NSCLC were feasible and safe.
\end{abstract}

Lung cancer is the leading cause of cancer deaths worldwide. Non-small cell lung cancer (NSCLC) accounts for

\footnotetext{
*These Authors contributed equally to this study.

Correspondence to: Professor Takuji Yamagami, M.D., Ph.D., Chairman, Department of Radiology, Kochi University, Kochi Medical School, Kohasu, Oko-cho, Nankoku, Kochi 783-8505, Japan. Tel: +81 888802367, Fax: +81 888802368, e-mail: yamagami@ kochi-u.ac.jp

Key Words: CT-guided biopsy, re-biopsy, non-small cell lung cancer, T790M mutation, programmed death-ligand 1.
}

approximately $80-85 \%$ of all lung cancer. Molecular-targeted therapies have been recently developed and provide a remarkable benefit to patients harboring specific genetic alterations such as mutations of the epidermal growth factor receptor (EGFR) gene (1). Despite an initial dramatic response, most patients receiving EGFR-tyrosine kinase inhibitors (TKIs) finally acquire resistance to such therapy. In approximately $50 \%$ of patients in Japan, the mechanism of acquired resistance is the development of an additional mutation, namely EGFR T790M (2). Therefore, it is clinically important to develop more effective therapies for patients with the EGFR T790M mutation. Indeed, third-generation EGFR-TKIs have been developed and have demonstrated remarkable efficacy in patients with the EGFR T790M mutation (3-5). With the spread of these third-generation EGFR-TKIs, an EGFR T790M status-based treatment selection has become essential in clinical practice after a patient has acquired resistance to EGFR-TKIs. In such patients, re-biopsy could provide further information, including the identification of histological or genetic changes, which may help identify patients eligible for treatment (6).

In parallel, immunotherapies are also evolving. For example, anti-programmed death-1 (PD1)/programmed death-ligand 1 (PD-L1) antibodies have demonstrated notable efficacy in patients with pretreated NSCLC. AntiPD1, such as nivolumab and pembrolizumab, have shown survival benefit in pretreated patients with NSCLC after failure of platinum doublet chemotherapies in randomized phase III trials compared to docetaxel monotherapy (7-10). Based on results of these trials, anti-PD1 monotherapies have become standard treatments for patients pretreated for NSCLC. Several predictive markers for anti-PD1/PD-L1 therapy have been developed. Among them, PD-L1 expression is the most widely investigated predictive marker 
for many types of cancer. Some studies of NSCLC demonstrated correlations between PD-L1 expression and response to anti-PD1/PD-L1 (8-10). Interestingly, previous chemotherapy for NSCLC may result in inconsistent PD-L1 expression $(11,12)$. Therefore, the use of fresh repeat biopsy samples may be desirable for examining PD-L1 expression.

Re-biopsy for patients with NSCLC has received much attention for the reasons noted above. Nosaki et al. reported that the success rate of percutaneous re-biopsy was higher than that of transbronchial re-biopsy and that CT-guided rebiopsy accounts for a significant proportion of percutaneous re-biopsies for patients with advanced or metastatic NSCLC who have completed first-line EGFR-TKI therapy (2). However, although there have been some reports on CTguided intrathoracic re-biopsy for NSCLC (13-15), to the best of our knowledge, no report has focused on the feasibility and safety of CT-guided bone re-biopsy including that of sclerotic bone lesions and bone lesions with an intact cortex in patients with NSCLC.

The aim of this study was to retrospectively determine the feasibility and safety of CT-guided intrathoracic and bone rebiopsy for patients with NSCLC.

\section{Materials and Methods}

Study design. The study was a multicenter, observational, retrospective study conducted with the approval of the Institutional Review Boards (17R-282) at three centers in Japan. Informed consent was obtained for every diagnostic or interventional procedure and the use of electronic medical records.

Patients. Between January 2017 and December 2017, 17 patients underwent re-biopsy for evaluation of EGFR T790M mutation and/or PD-L1 expression at three institutions. In all patients, the type of histology was adenocarcinoma which was resistant to treatment with conventional platinum-based chemotherapy or EGFR-TKIs. Table I shows the characteristics of the study patients.

CT-Guided biopsy was performed for intrathoracic lesions in 10 patients and for bone lesions in seven patients (Table II). An 18-G Temno biopsy needle (Bauer Medical, Clearwater, FL, USA), an 18G aspiration-type semi-automatic cutting biopsy needle (TSK Laboratory, Tochigi, Japan), or an 18-G Monopty biopsy needle (Bard, Covington, GA, USA) was used to sample intrathoracic lesions $(n=10)$ (Figure 1A) or soft-tissue lesions external to bone $(n=1)$. In biopsies for sclerotic bone lesions $(n=4)$, a 14-G Ostycut (Bard) or 13-G Osteosite (Cook Medical, Bloomington, IN, USA) bone biopsy needle was used to obtain tissue (Figure 1B). In biopsies for bone lesions with an intact cortex $(n=2)$, a $13-G$ Osteosite bone biopsy needle was used to obtain tissue and create a path for an 18 $\mathrm{G}$ Temno biopsy needle. The bone biopsy needle was then withdrawn, and an 18-G Temno biopsy needle was used to obtain a soft tissue sample from within the bone lesion (Figure 1C).

CT-Guided biopsy procedures. All patients had undergone diagnostic CT over the area where the target lesion was located with contiguous axial tomographic sections before re-biopsy. Prior to the re-biopsy, preliminary $\mathrm{CT}$ images were obtained that included the lesion and surrounding areas. From a review of these preliminary images, patient position, level of the needle entry site, and direction of the approach for biopsy were planned. The CT unit used was an Aquilion LB or ONE (Toshiba Medical System, Tokyo, Japan) or SOMATOM Definition AS 64 (Siemens Medical Solutions, Inc., Forchheim, Germany).

The procedure was performed with the patient under local anesthesia by one of six interventional radiologists (T. M., T. H., Y. B., K. C., R. Y., T. Y.) experienced in CT-guided biopsy. A CT fluoroscopic imaging system was used for all CT-guided re-biopsy procedures. Details of CT fluoroscopy were described elsewhere (16). An operator wearing a protective lead apron in the CT room was responsible for control of CT fluoroscopic exposure via a foot pedal and assisted in table movement and gantry tilt, and directed the laser light beam via the control panel. Intermittent real-time CT fluoroscopic technique (17) was preferred while advancing the biopsy needle, of which the center was held by surgical forceps, with the distal edge on the operator's side held by the operator's hand as necessary. This technique was performed in a stepwise manner with quick application of CT fluoroscopy to confirm the path of the needle, while meticulous care was taken to minimize direct radiation to the operator's hands. After confirming that the needle tip had reached the lesion, a specimen was obtained, and the needle was withdrawn.

After the re-biopsy procedure, axial CT images were obtained to determine the presence of complications.

EGFR-mutational analysis. The Cobas EGFR Mutation Test v2 or the peptide nucleic acid (PNA)-locked nucleic acid (LNA) PCR clamp-based test for the EGFR-mutation assays were performed by an outside laboratory (SRL, Inc., Tokyo, Japan or LSI Medicine Corporation, Tokyo, Japan).

PD-L1 immunohistochemistry. PD-L1 expression using the 22C3 antibody was assessed by an immunohistochemical assay performed by an outside laboratory (SRL, Inc., Tokyo, Japan) or within a participating institution. Scoring was recorded as the percentage of PD-L1-positive tumor cells among the total tumor cells assessed.

Parameters investigated. The following parameters were retrospectively investigated: maximum diameter of the lesion, time required for each re-biopsy procedure (time included the entire period that the patient was on the CT scanner table), number of punctures for each re-biopsy procedure, depth from the body surface to the edge of the mass biopsied, technical success rate, rate of success in obtaining sufficient samples for EGFR T790M mutational and PD-L1 expression analyses, and CT-guided re-biopsy-induced complications.

Statistical analysis. For statistical analysis, commercial software (JMP 12; SAS Japan, Tokyo, Japan) was used. Statistical analyses were performed using the Wilcoxon test for nonparametric data and the Fisher exact test for qualitative variables. Differences in results of the analyses were considered significant when the $p$-value was less than 0.05 .

\section{Results}

The mean [ \pm standard deviation (SD)] diameter of the 17 lesions was $40 \pm 18 \mathrm{~mm}$; range $=17$ to $79 \mathrm{~mm}(>10$ to $\leq 20 \mathrm{~mm}$ in two; $>20$ to $\leq 30 \mathrm{~mm}$ in three; $>30$ to $\leq 40 \mathrm{~mm}$ in five; $>40$ to $\leq 50 \mathrm{~mm}$ in one, and $>50 \mathrm{~mm}$ in six). The mean distance 
Table I. Basic characteristics of study patients $(n=17)$.

\begin{tabular}{lc}
\hline Characteristic & Value \\
\hline Age, years & \\
$\quad$ Median (range) & $72(44-83)$ \\
Gender, $\mathrm{n}$ & \\
$\quad$ Male & 11 \\
Female & 6 \\
Smoking, n & \\
$\quad$ No/yes & $8 / 9$ \\
Past/current & $7 / 2$ \\
Surgery, n & \\
No/yes & $10 / 7$ \\
\hline
\end{tabular}

Table II. Target biopsy locations $(n=17)^{*}$.

\begin{tabular}{lc}
\hline Intrathoracic $(\mathrm{n}=10)$ & 7 \\
Lung & 3 \\
Pleura & \\
Bone $(\mathrm{n}=7)$ & 5 (Thoracic: 2, lumbar: 2, sacral: 1) \\
Vertebra & 1 \\
Ishium & 1 \\
Rib & 1 \\
Ilium & 1 \\
\hline
\end{tabular}

*In one patient, a bone biopsy was performed for lesions of the sacrum and ilium.

from the skin to the edge of the target lesion was $54 \pm 19 \mathrm{~mm}$ (range $=11$ to $72 \mathrm{~mm}$ ). The mean time required for biopsy procedures was $24 \pm 9.3$ minutes (range $=13$ to 51 minutes). Overall, 39 punctures were performed among the 17 patients. The mean number of punctures in a single biopsy procedure was $2.3 \pm 1.2$ (range $=1$ to 5 , median $=2$ ). The technical success rate of the biopsy procedures was $100 \%$. For evaluation of EGFR T790M mutation/PD-L1 expression, specimens from 16 out of the 17 patients $(94 \%)$ were adequate. In one patient who underwent a CT-guided bone re-biopsy for a sclerotic bone lesion, the specimen was inadequate for mutational analysis owing to absence of a tumor component in the sample. EGFR T790M mutational analyses were conducted in 13 patients, with specimens being adequate in 12 of these patients. The specimens were obtained from intrathoracic lesions in six patients and from bone lesions in seven. Five out of the 12 patients with adequate specimens (42\%) had EGFR T790M mutations. Both EGFR T790M mutational analyses and PD-L1 expression analyses were conducted in nine patients. PD-L1 expression alone was analyzed for the remaining four patients, who had been diagnosed as having wild-type EGFR NSCLC in the first biopsy. Therefore, samples from a total of 13 patients were analyzed for PD-L1 expression. The specimens were obtained from intrathoracic
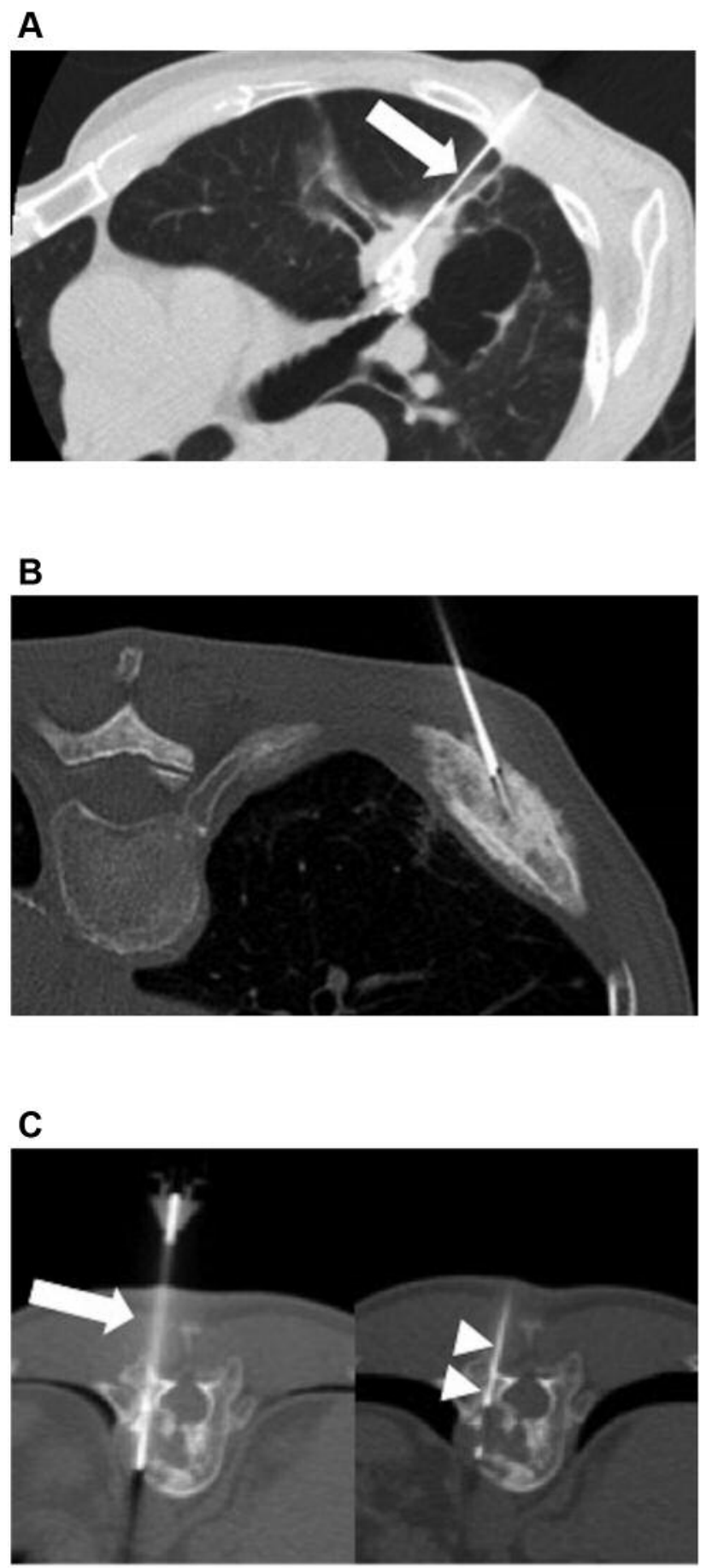

Figure 1. Computed tomography (CT)-guided biopsy. A: CT-guided intrathoracic biopsy. Fluoroscopic scan shows an 18-G biopsy needle (arrow) penetrating the lung nodule. B: CT-guided bone biopsy for bone sclerotic lesion. CT scan shows a 14-G bone biopsy needle (arrow) penetrating the rib metastasis. C: CT-guided bone biopsy for a bone lesion with an intact cortex. CT fluoroscopic scan shows a 13-G bone biopsy needle used to obtain tissue within an intact cortex to create a path for an 18-G biopsy needle (arrow). An 18-G biopsy needle was used to obtain soft tissue within the bone lesions (arrowheads) after withdrawal of the bone biopsy needle. 
Table III. Comparison between computed tomography-guided intrathoracic and bone re-biopsies.

\begin{tabular}{lccc}
\hline Target biopsy lesion & Intrathoracic $(\mathrm{n}=10)$ & Bone $(\mathrm{n}=7)$ & $p$-Value \\
\hline Maximum diameter of lesion (mm) & $47 \pm 19(23-79)$ & $31 \pm 13(17-55)$ & $0.0967^{*}$ \\
Time required for biopsy procedure (min) & $21 \pm 6.4(13-30)$ & $28 \pm 11(16-51)$ & $0.0946^{*}$ \\
Number of punctures & $2.0 \pm 1.2(1-5)$ & $2.7 \pm 1.1(1-4)$ & $0.1711^{*}$ \\
Depth from body surface to the edge of tumor mass (mm) & $62 \pm 8.8(46-72)$ & $43 \pm 25(1.1-71)$ & $0.1294^{*}$ \\
Rate of success in obtaining samples for T790M/PD-L1 analyses & $10 / 10(100 \%)$ & $6 / 7(86 \%)$ & $0.4118^{\#}$ \\
\hline
\end{tabular}

Data are means \pm SD (range) or n (\%). PD-L1: Programmed death-ligand 1. *Wilcoxon test, ${ }^{\#}$ Fisher exact test.

lesions in eight patients and bone lesions in five for PD-L1 expression analysis. For PD-L1 expression analysis, specimens from all patients were adequate.

There were no significant differences in any of the parameters between the CT-guided intrathoracic and bone rebiopsy groups (Table III).

Regarding CT-guided re-biopsy-induced complications, pneumothorax did not appear on CT images performed immediately after CT-guided intrathoracic re-biopsy. In two cases, parenchymal hemorrhage along the route of the biopsy needle was revealed on such CT images. In another case, asymptomatic air embolization, with stable cardiac and respiratory parameters were found on $\mathrm{CT}$ images obtained after CT-guided intrathoracic re-biopsy with the patient in a prone position. Chest CT scan images obtained 17 hours later revealed resorption of the pre-existing systemic air. No complications occurred after CT-guided bone re-biopsies.

\section{Discussion}

In this multicenter, observational, retrospective study, CTguided re-biopsy for EGFR T790M mutation and/or PD-L1 expression analysis achieved a high rate of success $(94 \%)$. The success rate in previously reported studies ranged between $73 \%$ and $95 \%(2,13,15,18-23)$.

There were no significant differences between CT-guided intrathoracic and bone re-biopsy. In addition, our findings suggest that both CT-guided intrathoracic and bone rebiopsies can be effectively utilized for evaluation of $E G F R$ T790M mutations and PD-L1 expression.

Previous studies also showed CT-guided lung re-biopsy to be feasible and safe in patients with NSCLC who developed resistance to conventional chemotherapy or EGFR-TKIs and who required repeat biopsies for mutational analysis (13-15). Regarding complications, Tsai et al. reported that complication rates for CT-guided re-biopsy were similar to previous studies of CT-guided biopsy (15). Indeed, no serious complications occurred in the present study. However, we had one case with asymptomatic systemic air embolization with stable cardiac and respiratory parameters after CT-guided intrathoracic re- biopsy. To the best of our knowledge, there have been no reports of systemic air embolization after CT-guided intrathoracic re-biopsy. Systemic air embolism is a potentially fatal complication and is thus of considerable concern. Although the risk of this complication was thought to be quite low, 0.02 to $0.07 \%$ according to a review of the literature for CT-guided biopsy (24-26), the frequency of systemic air embolization after CT-guided re-biopsy is unclear.

CT-Guided bone re-biopsy was feasible and safe in the present study. Confavreux et al. mentioned that CT-guided bone biopsy represents a safe and valuable option for molecular diagnosis in patients presenting lung tumors with synchronous bone metastasis using the EDTA-decalcification method, which provides good morphological results and high-quality DNA for performing molecular analysis (27). According to Nosaki et al., bone re-biopsies were performed in five $(4.2 \%)$ out of 121 re-biopsies (2). However, bone metastases were reported to occur in $30-50 \%$ of lung adenocarcinomas and may be synchronous in up to $15 \%$ of cases (28-30). Furthermore, such patients frequently suffer from emphysema, respiratory failure, or other co-morbidities precluding standard diagnostic procedures, such as fiberoptic bronchoscopy or percutaneous biopsy of the lung tumor, being safely conducted (30). In the present study, there were no complications related to CT-guided bone re-biopsy. Generally, the rate of complications with associated CTguided bone biopsies is very low. Rimondi et al. reported that complications occurred as a result of CT-guided bone biopsies in 22 cases $(1.1 \%)$ out of 2027 CT-guided biopsies of lesions in the musculoskeletal system: with 18 cases of transient lower limb paresthesia, three of hematoma in the psoas muscle, and one of retroperitoneal hematoma. These 22 complications neither affected the treatment strategy nor overall patient outcome (31).

There are some limitations to the present study, the first being its retrospective nature. Secondly, this study was limited by its small sample size; however, we focused on feasibility and safety of CT-guided re-biopsy in not only intrathoracic but also bone re-biopsy, including that of sclerotic bone lesions and bone lesions with an intact cortex. 
In conclusion, both CT-guided intrathoracic and bone rebiopsies for patients with NSCLC were feasible and safe.

\section{Conflicts of Interest}

On behalf of all Authors, the corresponding Author states that there is no conflict of interest in regard to this study.

\section{Ethical Approval}

All procedures performed in studies involving human participants were in accordance with the ethical standards of the institutional and/or national research committee and with the 1964 Helsinki declaration and its later amendments or comparable ethical standards. This article does not include any animal studies performed by any of the Authors.

\section{Informed Consent}

Informed consent was obtained from all individual participants included in the study for every diagnostic and interventional procedure and the use of electronic medical records.

\section{Acknowledgements}

The Authors would like to thank Dr. Yusuke Nakamura of the Department of General Thoracic Surgery, Tokai University Hachioji Hospital, for their help in patient management;and Dr. Kazunobu Hashida, Dr. Kosuke Tomita and Dr. Satoshi Suda of the Department of Radiology, Tokai University Hachioji Hospital, Tokai University School of Medicine, for continuing support and encouragement

\section{References}

1 Lynch TJ, Bell DW, Sordella R, Gurubhagavatula S, Okimoto RA, Brannigan BW, Harris PL, Haserlat SM, Supko JG, Haluska FG, Louis DN, Christiani DC, Settleman J and Haber DA: Activating mutations in the epidermal growth factor receptor underlying responsiveness of non-small-cell lung cancer to gefitinib. N Engl J Med 350: 2129-2139, 2004.

2 Nosaki K, Satouchi M, Kurata T, Yoshida T, Okamoto I, Katakami N, Imamura F, Tanaka K, Yamane Y, Yamamoto N, Kato T, Kiura K, Saka H, Yoshioka H, Watanabe K, Mizuno K and Seto T: Rebiopsy status among non-small cell lung cancer patients in Japan: A retrospective study. Lung Cancer 101: 1-8, 2016.

3 Janne PA, Yang JC, Kim DW, Planchard D, Ohe Y, Ramalingam SS, Ahn MJ, Kim SW, Su WC, Horn L, Haggstrom D, Felip E, Kim JH, Frewer P, Cantarini M, Brown KH, Dickinson PA, Ghiorghiu S and Ranson M: AZD9291 in EGFR inhibitor-resistant non-small-cell lung cancer. N Engl J Med 372: 1689-1699, 2015.

4 Sequist LV, Soria JC, Goldman JW, Wakelee HA, Gadgeel SM, Varga A, Papadimitrakopoulou V, Solomon BJ, Oxnard GR, Dziadziuszko R, Aisner DL, Doebele RC, Galasso C, Garon EB, Heist RS, Logan J, Neal JW, Mendenhall MA, Nichols S, Piotrowska Z, Wozniak AJ, Raponi M, Karlovich CA, Jaw-Tsai S, Isaacson J, Despain D, Matheny SL, Rolfe L, Allen AR and Camidge DR: Rociletinib in EGFR-mutated non-small-cell lung cancer. N Engl J Med 372: 1700-1709, 2015.
5 Mok TS, Wu YL, Ahn MJ, Garassino MC, Kim HR, Ramalingam SS, Shepherd FA, He Y, Akamatsu H, Theelen WS, Lee CK, Sebastian M, Templeton A, Mann H, Marotti M, Ghiorghiu S and Papadimitrakopoulou VA: Osimertinib or platinum-pemetrexed in EGFR T790M-positive lung cancer. N Engl J Med 376: 629-640, 2017.

6 Suda K, Murakami I, Sakai K, Mizuuchi H, Shimizu S, Sato K, Tomizawa K, Tomida S, Yatabe Y, Nishio K and Mitsudomi T: Small cell lung cancer transformation and T790M mutation: complimentary roles in acquired resistance to kinase inhibitors in lung cancer. Sci Rep 5: 14447, 2015.

7 Brahmer J, Reckamp KL, Baas P, Crino L, Eberhardt WE, Poddubskaya E, Antonia S, Pluzanski A, Vokes EE, Holgado E, Waterhouse D, Ready N, Gainor J, Aren Frontera O, Havel L, Steins M, Garassino MC, Aerts JG, Domine M, Paz-Ares L, Reck M, Baudelet C, Harbison CT, Lestini B and Spigel DR: Nivolumab versus docetaxel in advanced squamous-cell nonsmall-cell lung cancer. N Engl J Med 373: 123-135, 2015.

8 Borghaei H, Paz-Ares L, Horn L, Spigel DR, Steins M, Ready NE, Chow LQ, Vokes EE, Felip E, Holgado E, Barlesi F, Kohlhaufl M, Arrieta O, Burgio MA, Fayette J, Lena H, Poddubskaya E, Gerber DE, Gettinger SN, Rudin CM, Rizvi N, Crino L, Blumenschein GR Jr., Antonia SJ, Dorange C, Harbison $\mathrm{CT}$, Graf Finckenstein $\mathrm{F}$ and Brahmer JR: Nivolumab versus docetaxel in advanced nonsquamous non-small-cell lung cancer. N Engl J Med 373: 1627-1639, 2015.

9 Herbst RS, Baas P, Kim DW, Felip E, Perez-Gracia JL, Han JY, Molina J, Kim JH, Arvis CD, Ahn MJ, Majem M, Fidler MJ, de Castro G, Jr., Garrido M, Lubiniecki GM, Shentu Y, Im E, Dolled-Filhart $\mathrm{M}$ and Garon EB: Pembrolizumab versus docetaxel for previously treated, PD-L1-positive, advanced nonsmall-cell lung cancer (KEYNOTE-010): a randomised controlled trial. Lancet 387: 1540-1550, 2016.

10 Rittmeyer A, Barlesi F, Waterkamp D, Park K, Ciardiello F, von Pawel J, Gadgeel SM, Hida T, Kowalski DM, Dols MC, Cortinovis DL, Leach J, Polikoff J, Barrios C, Kabbinavar F, Frontera OA, De Marinis F, Turna H, Lee JS, Ballinger M, Kowanetz M, He P, Chen DS, Sandler A and Gandara DR: Atezolizumab versus docetaxel in patients with previously treated non-small-cell lung cancer (OAK): a phase 3, open-label, multicentre randomised controlled trial. Lancet 389: 255-265, 2017.

11 Sheng J, Fang W, Yu J, Chen N, Zhan J, Ma Y, Yang Y, Huang $\mathrm{Y}$, Zhao $\mathrm{H}$ and Zhang L: Expression of programmed death ligand-1 on tumor cells varies pre and post chemotherapy in non-small cell lung cancer. Sci Rep 6: 20090, 2016.

12 Haratake N, Toyokawa G, Tagawa T, Kozuma Y, Matsubara T, Takamori S, Akamine T, Yamada Y, Oda Y and Maehara Y: Positive conversion of PD-L1 expression after treatments with chemotherapy and nivolumab. Anticancer Res 37: 5713-5717, 2017.

13 Yoon HJ, Lee HY, Lee KS, Choi YL, Ahn MJ, Park K, Ahn JS, Sun JM, Kim J, Kim TS, Chung MJ and Yi CA: Repeat biopsy for mutational analysis of non-small cell lung cancers resistant to previous chemotherapy: adequacy and complications. Radiology 265: 939-948, 2012.

14 Kim H, Chae KJ, Yoon SH, Kim M, Keam B, Kim TM, Kim DW, Goo JM and Park CM: Repeat biopsy of patients with acquired resistance to EGFR TKIs: Implications of biopsyrelated factors on T790M mutation detection. Eur Radiol 28: 861-868, 2018 
15 Tsai EB, Pomykala K, Ruchalski K, Genshaft S, Abtin F, Gutierrez A, Kim HJ, Li A, Adame C, Jalalian A, Wolf B, Garon EB, Goldman JW and Suh R: Feasibility and safety of intrathoracic biopsy and repeat biopsy for evaluation of programmed cell death ligand-1 expression for immunotherapy in non-small cell lung cancer. Radiology, 2017. doi: 10.1148/radiol.2017170347

16 Katada K, Kato R, Anno H, Ogura Y, Koga S, Ida Y, Sato M and Nonomura K: Guidance with real-time CT fluoroscopy: Early clinical experience. Radiology 200: 851-856, 1996.

17 Daly B and Templeton PA: Real-time CT fluoroscopy: Evolution of an interventional tool. Radiology 211: 309-315, 1999.

18 Arcila ME, Oxnard GR, Nafa K, Riely GJ, Solomon SB, Zakowski MF, Kris MG, Pao W, Miller VA and Ladanyi M: Rebiopsy of lung cancer patients with acquired resistance to EGFR inhibitors and enhanced detection of the T790M mutation using a locked nucleic acid-based assay. Clin Cancer Res 17: 1169-1180, 2011.

19 Chouaid C, Dujon C, Do P, Monnet I, Madroszyk A, Le Caer H, Auliac JB, Berard H, Thomas P, Lena H, Robinet G, Baize N, Bizieux-Thaminy A, Fraboulet G, Locher C, Le Treut J, Hominal $\mathrm{S}$ and Vergnenegre A: Feasibility and clinical impact of rebiopsy in advanced non small-cell lung cancer: a prospective multicenter study in a real-world setting (GFPC study 12-01). Lung Cancer 86: 170-173, 2014.

20 Kuiper JL, Heideman DA, Thunnissen E, Paul MA, van Wijk AW, Postmus PE and Smit EF: Incidence of T790M mutation in (sequential) rebiopsies in EGFR-mutated NSCLC patients. Lung Cancer 85: 19-24, 2014.

21 Bosc C, Ferretti GR, Cadranel J, Audigier-Valette C, Besse B, Barlesi F, Decroisette C, Lantuejoul S, Arbib F and Moro-Sibilot D: Rebiopsy during disease progression in patients treated by TKI for oncogene-addicted NSCLC. Target Oncol 10: 247-253, 2015.

22 Kawamura T, Kenmotsu H, Taira T, Omori S, Nakashima K, Wakuda K, Ono A, Naito T, Murakami H, Mori K, Nakajima T, Ohde Y, Endo M and Takahashi T: Rebiopsy for patients with nonsmall-cell lung cancer after epidermal growth factor receptortyrosine kinase inhibitor failure. Cancer Sci 107: 1001-1005, 2016.

23 Kirita K, Izumo T, Matsumoto Y, Hiraishi Y and Tsuchida T: Bronchoscopic re-biopsy for mutational analysis of non-small cell lung cancer. Lung 194: 371-378, 2016.
24 Sinner WN: Complications of percutaneous transthoracic needle aspiration biopsy. Acta Radiol Diagn 17: 813-828, 1976.

25 Richardson CM, Pointon KS, Manhire AR and Macfarlane JT: Percutaneous lung biopsies: A survey of UK practice based on 5444 biopsies. Br J Radiol 75: 731-735, 2002.

26 Tomiyama N, Yasuhara Y, Nakajima Y, Adachi S, Arai Y, Kusumoto M, Eguchi K, Kuriyama K, Sakai F, Noguchi M, Murata K, Murayama S, Mochizuki T, Mori K and Yamada K: CT-guided needle biopsy of lung lesions: A survey of severe complication based on 9783 biopsies in Japan. Eur J Radiol 59: 60-64, 2006.

27 Confavreux CB, Girard N, Pialat JB, Bringuier PP, Devouassoux-Shisheboran M, Rousseau JC, Isaac S, ThivoletBejui F, Clezardin P and Brevet M: Mutational profiling of bone metastases from lung adenocarcinoma: results of a prospective study (POUMOS-TEC). Bonekey Rep 3: 580, 2014.

28 Nottebaert M, Exner GU, von Hochstetter AR and Schreiber A: Metastatic bone disease from occult carcinoma: a profile. Int Orthop 13: 119-123, 1989.

29 Coleman RE: Clinical features of metastatic bone disease and risk of skeletal morbidity. Clin Cancer Res 12: 6243s-6249s, 2006.

30 Decroisette C, Monnet I, Berard H, Quere G, Le Caer H, Bota S, Audigier-Valette C, Geriniere L, Vernejoux JM and Chouaid $\mathrm{C}$ : Epidemiology and treatment costs of bone metastases from lung cancer: a French prospective, observational, multicenter study (GFPC 0601). J Thorac Oncol 6: 576-582, 2011.

31 Rimondi E, Rossi G, Bartalena T, Ciminari R, Alberghini M, Ruggieri P, Errani C, Angelini A, Calabro T, Abati CN, Balladelli A, Tranfaglia C, Mavrogenis AF, Vanel D and Mercuri M: Percutaneous CT-guided biopsy of the musculoskeletal system: results of 2027 cases. Eur J Radiol 77: 34-42, 2011.

Received April 3, 2018

Revised May 8, 2018

Accepted May 9, 2018 